\title{
VI. Comparative analysis of human bones, and those of different animals
}

\section{Merat-Guillot}

To cite this article: C. Merat-Guillot (1800) VI. Comparative analysis of human bones, and those of different animals, Philosophical Magazine Series 1, 7:26, 131-134, DOI: $10.1080 / 14786440008562561$

To link to this article: http://dx.doi.org/10.1080/14786440008562561

曲 Published online: 18 May 2009.

Submit your article to this journal $\sqsubset \pi$

Џ Article views: 2

Q View related articles $\square$ 
thank likewife informs me, that after the combuftion of good gunpowder under mercury, no water is ever perceptible.

\section{References to the Figures of the Glas Globe, Ge. mentioned in Secizon VII. (See Plate VIII.)}

A, a ball or globe of glafs, nearly half an inch thick, and feven inches in diameter. It has two necks, on which are cenented the brals caps B, C, each being perforated with a female fcrew to receive the male ones $D, E$ : through the former a fnill hole is drilled; the latter is furnifhed with a perforated ftud or hank $G$. By means of a leather collar $\mathrm{H}$, the neck $\mathrm{C}$ can be air-tightly clofed. When a portion of the powder is to be exploded, it muft be placed on a piece of paper, and a fmall wire laid acrofs the paper, through the. midft of the powder: the paper being then clofed, is to be tied at each end to the wire, with a filken thread, as thown at I. One end of this wire is to be faftened to the end of the fhank $G$, and the forew $D$ inferted to half its length into the brafs cap $B$; the other end of the wire, $a$, by means of the needle $\mathrm{K}$, is to be drawn through the hole $\mathrm{F}$. The forew E being now fixed in its place, and the wire drawn tight, it is to be fecured by puthing the irregular wooden plug $\mathrm{L}$ into the aperture of the forew $D$, taking care to leave a paffage for air. The ftop-cock M, the fection of which is thown at $N_{\text {g }}$ is now to be fcrewed on to the part $D$, which is made airtight by the leather collar $b$. The glafs tube $\mathrm{O}$ is bent, that it may nore conveniently be introduced under the receiver of a pneumatic apparatus. P fhows the manner of connesting the glafs tube with the ftock-cock.

VI. Comparaive Analy is of Human Bones, and those of different Animals. By C. Merat-Gupllot, Apotbeary at Auxerre*.

DUfFON fays, "We ought to collect objects of every kind, to compare them, to ftudy their nature, and from their combined relations to deduce that information which may

* Fiom the Ansales de Cobimie, No: 100. 
enable us to acquire a clear conception of them, and to increafe our knowledge refpecting them *." Fourcroy obferves, in his Elements of Chemiftry, under the head Bone, that 's We cannot refufe believing that the bones of man and of quadrupeds are of a different nature from the foft and flexible bones of fifhes, reptiles, and, above all, the corneous fkeletons of infects, as.well as from the calcareous teftaceous covering of worms which have thells."

Being defirous to afcertain the truth of what had been advanced by C. Fourcroy, and guided by what is prefcribed by Buffon in the treatife above mentioned, I undertook a labour, fuperior, no doubt, to my ability, and in which it is poffible I may have been deceived, but which I fubmit to the judgment of thofe who are mafters in the art. I was defirous of procuring all the objects which it was neceffary thould be fubjected to comparifon, fuch as a feries of human bones, from which I might trace out the progrefs of offification; but as I could not, and wilhing to know at leaft the difference between products of animal bones at an early age, and thofe of the fame animal at an advaneed age, I employed for that purpofe the bones of oxen and calves. I wanted, to complete my experimetits in this analyfis, the bones of carnivorous animals, the fkeletons of infects, \&c, When I am able to procure them, I thall refume my labours,

Being defirous to comprehend in this analyfis, hair, corncous fubftances, and the briftles of different animals, I remarked, when treating the firft of thefe fubftances with cauftic foda, by means of heat, that there was produced a confiderable difengagement of ammonia; that in pouring into this folution the muriatic acid, there was difengaged fulphurated hydrogen, and that a blackifh precipitate, but in very fmall quantity, was thrown down. Having boiled this liquor, there was ftill difengaged a great deal of fulphurated hydrogen, from which I conjectured that it contained fulphur; and this fact I withed to afcertain. With that view, I put a filver fpoon into the liquid, and again boiled it; the fpoon became exceedingly black, and I thence concluded that the hair contained fulphur. As this labour prefented

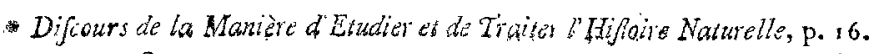


peculiar refults, which cannot be compared with the analyfis here given, I intend, having already collected notes on that fubject, to make a particular analyfis of this fubftance compared with that of other fubftances of an analogous nature.

It is to be obferved that I always operated on 100 parts of each fubftance, and that all the products, the quantities of which I determined, had been previoufly dried as much as poffible.

\begin{tabular}{|c|c|c|c|c|}
\hline $\begin{array}{l}\text { Names of the } \\
\text { Subftances. }\end{array}$ & $\mid \begin{array}{c}\text { Proportions of } \\
\text { Gelatinous } \\
\text { Matter. }\end{array}$ & $\begin{array}{c}\text { Proportions of } \\
\text { the Phofphat } \\
\text { of Lime. }\end{array}$ & $\mid \begin{array}{c}\text { Proportions of } \\
\text { the Carbonat } \\
\text { of Lime. }\end{array}$ & Lof. \\
\hline 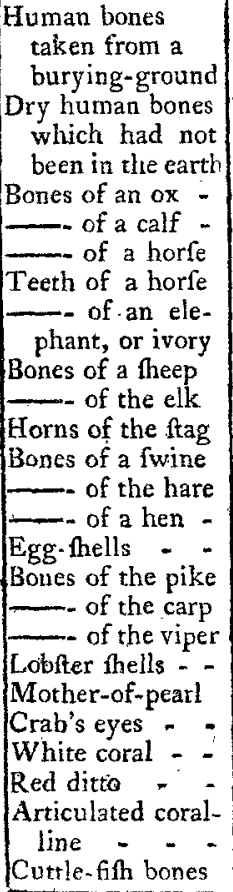 & $\begin{array}{l}23 \\
3 \\
25 \\
9 \\
12 \\
24 \\
16 \\
1.5 \\
27 \\
17 \\
9 \\
6 \\
3 \\
12 \\
6 \\
21.5 \\
18 \\
2.5 \\
2 \\
1.5 \\
0.5 \\
7.5 * \\
8\end{array}$ & $\begin{array}{l}63 \\
93 \\
54 \\
67.5 \\
85.5 \\
64 \\
64 \\
70 \\
90 \\
57.5 \\
52 \\
85 \\
72 \\
2 \\
64 \\
45 \\
60.5 \\
14 \\
0 \\
12 \\
0 \\
0 \\
\\
0 \\
0\end{array}$ & $\begin{array}{c}2 \\
2 \\
\text { traces of it }^{2} \\
1.25 \\
0.25 \\
0.1 \\
0.5 \\
1 \\
1 \\
1 \\
1 \\
1 \cdot 5 \\
72 \\
1 \\
0.5 \\
0.5 \\
40 \\
66 \\
60 \\
50 \\
53^{\circ} 5 \\
49 \\
68\end{array}$ & 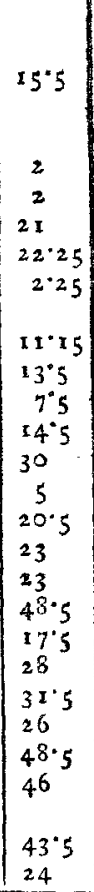 \\
\hline
\end{tabular}

Being defirous to afcertain whence arofe the lofs experienced in each analyfis, I fubjected to a ftrong heat Ioo parts

* The product which I place under the head of Gelatinous Matter, is not entirely compofed of that fubftance. In my opinion it contains a portion of a fubrtance' analogous in its nature to that which forms the polypiess known under the name of lithopbytes. 
of crabs eyes: they decreafed 22 parts, and for that reafon, I prefume that this lofs might be afcribed to the water which is found, at leaft in the gelatinous matter, fince it is dried as nuich as poflible; but as there ftill remains four parts, 1 afcribe the lofs to a portion of the gelatinous matter which is found diffolved in the liquid employed for the analyfis, and to a fmall quantity of a faline fubftance which $I$ did not examine, and which may be diffolved in it. Should thrs effay. be of any utility, the end I propofed will be anfwered*.

VII. Metbod of determining the Quantity of Sulphur and Iron contained in Yellow Copper Ore. By B. G. SAGE, Director of the firft Scbool of Minest.

T

HE colour of this ore is a bright yellow inclining to that of gold; on the furface of it there is often obferved red. difh, violet, purple, and greenith blue varying thades, on which account it has been called peacock's-tail or pigeon's-neck copper ore. The form of this yellow copper ore is the equilateral tetraedron and its varieties. Though it is rare to find thefe cryftals regular, the ore, in a compact, irregular, and fometimes lamellated mafs, is very common; fome of it is. met with in the fchiftous impreffions of fin found at Eineben. and Mansfeld.

I have faid, in the fecond volume of my Mineralogy, that the yellow copper ore always contains iron and fulphur in greater or lefs quantity: the proportions I have been able to determine by the following experiments. The yellow copper ore which I employed had no matrix. Having pulverifed it in a copper mortar, four hundred grains of it were expofed to torrefaction in a teft, but, as it was too mach heated, the ore became fufed, and produced a yellow cosapaet brilliant mafs, which had a violet appearance in fome parts of it's fracture. This ore was not in the ftate of nag; that is to fay, in a black mafs, as is the cafe when torrefied on a Jarge feale.

$\approx$ This analyfis agrees pretty well with that of Mr. Hatchett already given in this Magazine, Nes. $2 x$ and 24 .

+ From the Fournal de Pbyfrze, Prairial, an. 8.' 